\title{
Mechanical Property Evaluation of Banana Jute Fibre Along with Carbon Fibre Epoxy Composite Material
}

\author{
U. Tamilarasan, P.V. Inbanaathan
}

\begin{abstract}
Fibre composites are nowadays being used in various engineering applications to increase the strength and optimize the weight and the cost of the product. In engineering field, usage of composite material is gradually growing. Due to the vast concrns in natural composites made out from the natural fibred resin is said to be one the new advancement in many fields. This gave the idea of this present work. In this paper, an experimental investigation has been carried out to utilize the fibre extracted from banana and convert it into valuable product which are to be used in our day to day life. A Specimen is fabricated by hybridisation of Natural fibres (Banana \& Jute fibres) along with the epoxy resin. Another Specimen is fabricated by hybridisation of Fibre (Banana, Jute \& Carbon Fibre) along with the help of epoxy Resin. Experiments are carried out as per American Standard of Testing and Materials (ASTM) to find the mechanical property of both specimens. In World wide, scientists have took the work of accessing the chracteristics of various fibres which are eaily accessible and cheaper in cost availability by using various ASTM standards. This work is one among the researches in accessing the low cost easily accessible fibre to make it feasible for the usage. Various effects of loading on the length of the prepared specimen and various mechanical properties like flexural strength, tensile strength of the prepard specimens are studied.
\end{abstract}

Keywords-composite,bananafibre,jutefibre, carbon fibre,

\section{INTRODUCTION}

No distinct material can provide the various characteristics for enhancement in usage in which fibre composites are exceptional materials. The fibre is made up of many compatible materials which are different in composition combine physically to form a structure in a cohesive manner. Thinking in a broader category, the combinations of various fibres has its self distinct characterization. Many reserchers clearly say that combining two materials alone will not make an effective fibre in terms of tensile, flexural and impact strength, heat resistance. The author [1] has defined that to obtain good improved materials, many alloys which are different in materials can be combined in which the combined specimen can take only its good characteristics and not its poor characteristics. Author [2] defines the composite as heterogeneous materials with more phases of solids in contact with each other on a very minute scale. It can also be a homogenous material in which it should have same physical property on any of the shape and size of the object in a very minute scale.

Revised Manuscript Received on 14 August, 2019.

Dr. U. Tamilarasan, Prof. and Head, Dpt. of Prod. Engg. Sri SairamEngg. College, Chennai, Tamil Nadu, India.

Mr. P.V. Inbanaathan, Asst. Prof., Dpt. of Prod. Engg. Sri SairamEngg. College, Chennai, Tamil Nadu, India. tensile, flexural

\section{A. $\quad$ Need}

There is a world wide demand of newly improved materials with better characteristics. All desired mechanical properties cannot be identified in a single material. To quote an example a material with high impact strength would be effective in terms of the cost and availability of the material. Various applications requires many desirable properties which are listed below:

$\begin{array}{ll}\text { - } & \text { Tensile Strength } \\ \text { - } & \text { Impact Strength } \\ \text { - } & \text { High fatigue } \\ \text { - } & \text { Surface roughness } \\ \text { - } & \text { Delamination } \\ \text { - } & \text { Toughness } \\ \text { - } & \text { Roundness } \\ \text { - } & \text { High corrosion, chemical and wear resistance } \\ \text { - } & \text { Acoustic and Thermal insulation } \\ \text { - } & \text { Cost Effectiveness }\end{array}$

The above mentioned list would get enhanced according to the years to go with various newly build materials to come. So, the designing of the required properties depends mostly on the application at where it is going to be used effectively.

\section{B. Overview of fibre and Composites}

In last few years, usage of wood and plant fibre along with the plastics has been increased. Natural fibre which are biodegradable are increasing in the usage in comparison to the glass fibre. In general these fibre have netter stiffness and strength.

\section{Classification of Natural Fibres}

There are two major classifications in fibres: one is natural fibre and the nother one is synthetic fibre. These are very thin materials with various continuous filaments which are similar to thread pieces.

\section{Fibres from plants}

These are fibres which are obtained from plants like cotton, bamboo, coir, flex, jute etc.

Wood fibre - Cotton fibre - excellent tensile property applied in packaging

Friutfibre - Banana fibre - excellent flexural property applied in boxing 

EPOXY COMPOSITE MATERIAL

\section{E. Fibres from minerals}

These are the fibre which are obtained from various available minerals.

Asbestos - mineral fibre - constitutents - aluminium oxide, boron carbide and metal filaments

\section{F. $\quad$ Fibres from animals}

These are the kind of fibre which are obtained from dry saliva, skin, hair of the various animals in the forest.

Goat hair, hair of alpaca, downy of sheep - animal fibre good impact strength - applied in various engineering applications.

\section{G. Composite types}

In general, the composite materials are classified according to the arrangement of materials matrix as follows:

1. Metal matrix composite materials - composite containing metal inside the fibres

2. Polymer matrix composite materials - composite containing various polmers layers

3. Ceramic matrix composite materials - composite containing ceramic dispered phases

\section{RESEARCH OBJECTIVES}

The foremost objectives of the current research work are as follows:

1. Fabricating the fibre reinforced Composites with natural fibres and also with carbon fibre

2. To estimate the mechanical properties such as tensile strength and flexural strength

3. To find better application for the composites

\section{EXPERIMENTAL STUDY}

The materials used in this research work are:

1. Carbon Fibre

2. Banana fibre

3. Jute Fibre

4. Epoxy

5. Resin and Hardener

\section{Carbon Fibre}

To form a composite material, the carbon fibre are combined with other materials. It takes a name as carbon fibre reinforced polymer when it is joined with a plastic resin material and it gives a very high resistance to wear, corrosion and high strength to weight ratio. It is rigid though it is brittle. It can vary in $5-10 \mu \mathrm{m}$ size in diameter which is mostly consisiting only of the carbon atoms. The figure 1 represents the prepared carbon fibre.

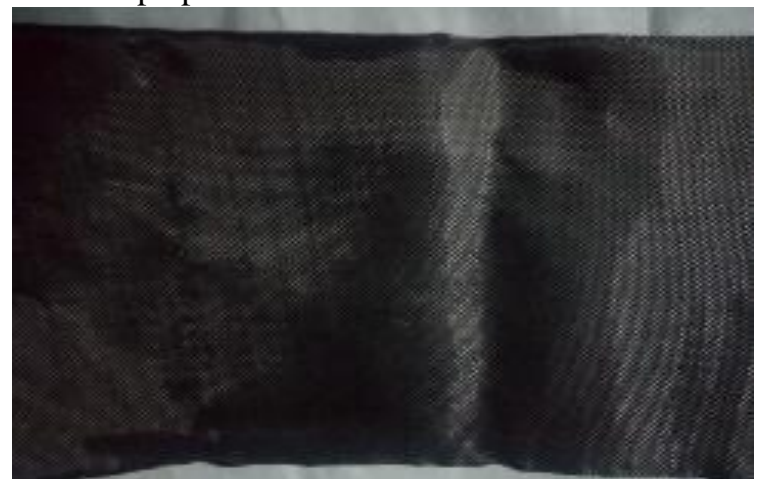

Figure 1 Carbon Fibre

\section{Banana Fibre}

The banana plant's pseudo stem sheath is used to extract the banana fibre. This extraction of the fibre is one by using mechanical extraction method. It will be dried for a day after extraction. Then it will be packed in high polyethylene bags. It should be kept away from moisture and light. Pillows, cushions, matressetc in furniture insutries use mainly the banana fibres. The figure 2 depicts the prepard banana fibre.

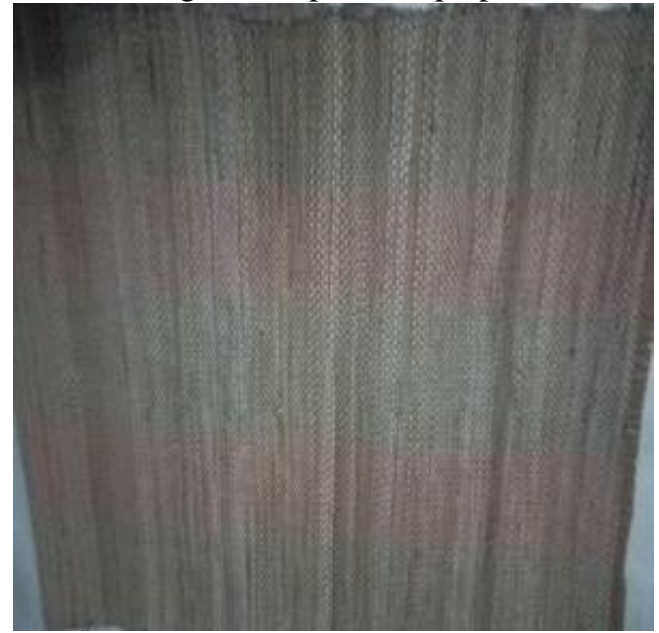

Figure 2 Banana Fibre

\section{Jute Fibre}

These are the fibre prepared from malvaceae family vegetables which are spun into strong threads. These fibre are $1-4 \mathrm{~m}$ in length and looks whitish brown in colour. It is often called as golden fibre for its colour. The figure 3 represents the prepared jute fibre. The table 2 and 3 represents the mechanical properties and chemical composition of jute, banana fibre respectively.

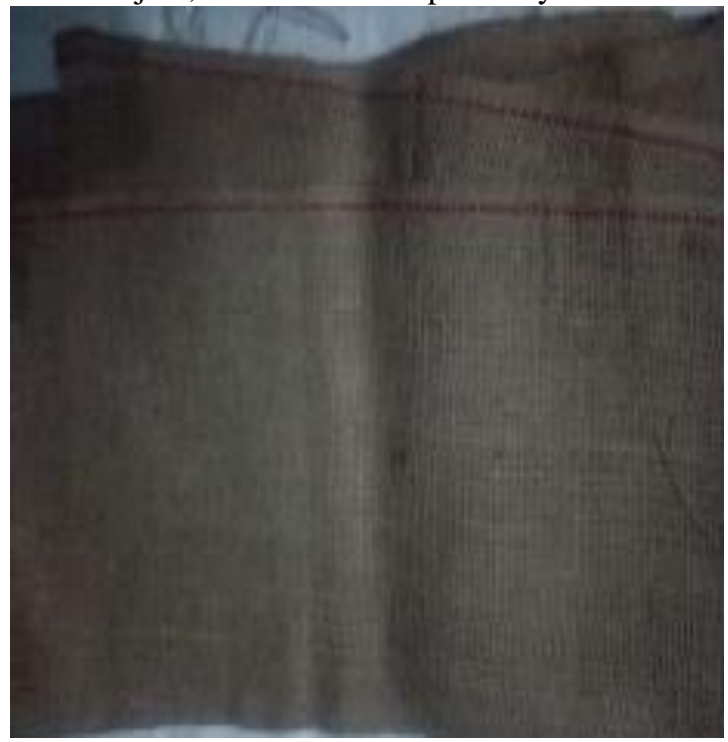

Fig. 3. Jute Fibre

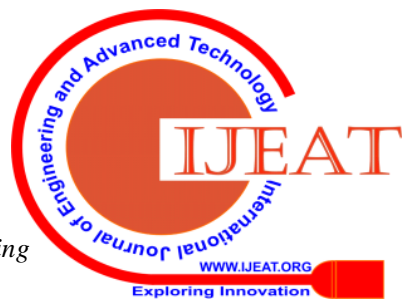


Table 1 Mechanical Properties of Jute and Banana Fibre

\begin{tabular}{|l|l|l|l|l|l|}
\hline $\begin{array}{l}\text { Fibre } \\
\text { Type }\end{array}$ & $\begin{array}{l}\text { Tensile } \\
\text { Strength } \\
\text { (Mpa) }\end{array}$ & $\begin{array}{l}\text { Specific } \\
\text { Tensile } \\
\text { Strength } \\
\text { (Mpa) }\end{array}$ & $\begin{array}{l}\text { Young's } \\
\text { Modulus } \\
\text { (Gpa) }\end{array}$ & $\begin{array}{l}\text { Specific } \\
\text { Young's } \\
\text { Modulus } \\
\text { (Gpa) }\end{array}$ & $\begin{array}{l}\text { Failure } \\
\text { Strain } \\
(\%)\end{array}$ \\
\hline Jute & $\begin{array}{l}200- \\
450\end{array}$ & $140-320$ & $20-55$ & $14-39$ & $2-3$ \\
Banana & $\begin{array}{l}529- \\
914\end{array}$ & $392-677$ & $27-32$ & $20-24$ & $1-3$ \\
\hline
\end{tabular}

Table 2 Chemical composition of jute and banana fibre

\begin{tabular}{|c|c|c|c|c|}
\hline $\begin{array}{c}\text { Fiber } \\
\text { Type }\end{array}$ & Cellulose & $\begin{array}{c}\text { Hemi } \\
\text { cellulose }\end{array}$ & Lignin & Pectin \\
\hline Jute & $51-84$ & $12-20$ & $5-13$ & 0.2 \\
Banana & $60-65$ & $6-19$ & $5-10$ & $3-5$ \\
\hline
\end{tabular}

\section{Resin and Hardener}

The figure 4 depicts the hardener and resin used for the research work. The Epoxy Resin used in this study are Araldite LY556 and Araldite HY951 (Hardener). The Importance of these Epoxy Resins are:

- Industrial composites

- Excellent mechanical property

- Resistor to chemicals

- Better electrical resistance.

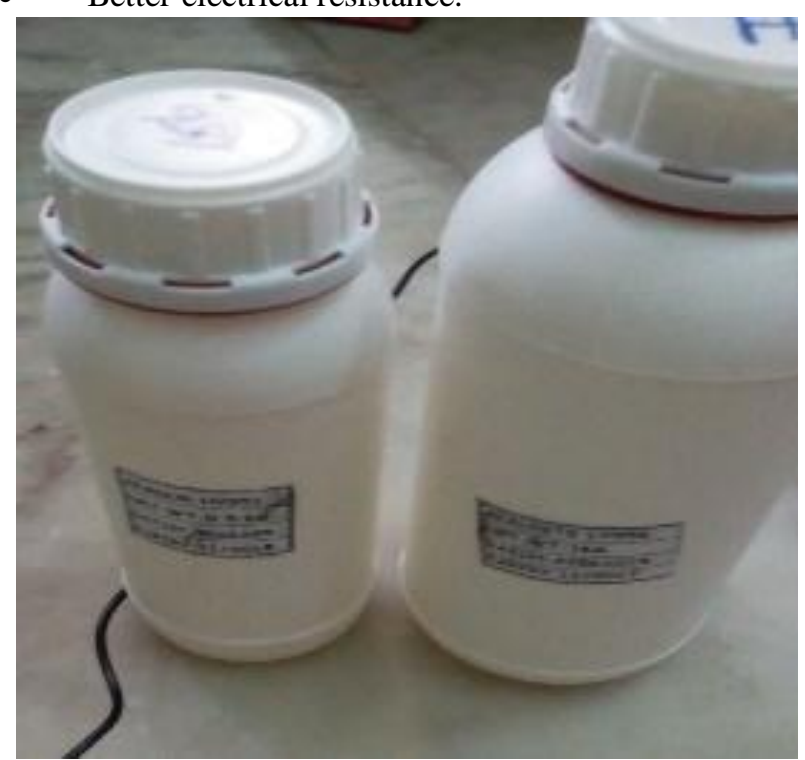

Figure 4 Hardener \& Resin

\section{PREPARATION OF SPECIMENS}

In this experimental investigation, two specimens are made with Banana and Jute Fibre. In the Second Specimen, Carbon fibre is added. The hardener like epoxy (Araldite LY556) and Araldite HY951 is used to manufacture the composite combination. The Composite plates are prepared by Hand layup method. The figure 5 shows the set up pf the hand lay up technique used.

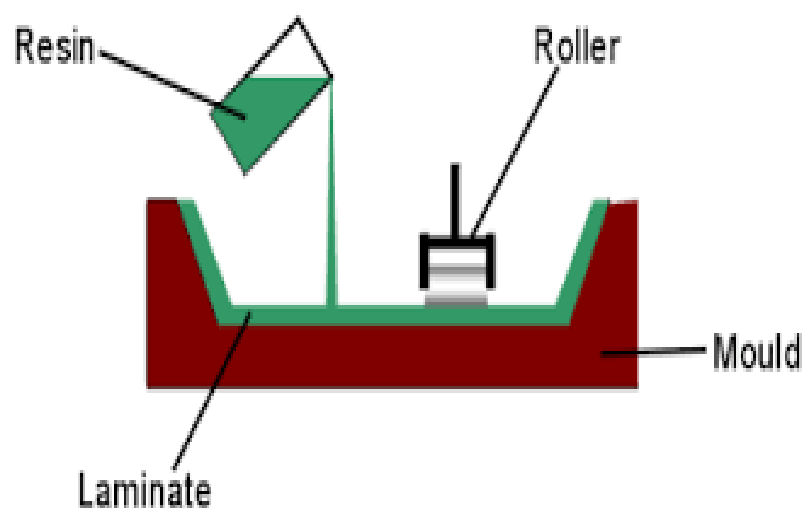

Figure 5 Hand Lay-up technique

Specimen A consist only of natural fibres (banana and jute). The Composite is prepared by Hand lay-up technique. Jute Fibre is set as base material. Banana Fibre and Jute Fibre are kept over other consisting of 7 layers. At the end of the process thickness is $6.7 \mathrm{~mm}$. The figure 6 represents the composition of specimen A. The figure 7 depicts the prepared specimen A.

\begin{tabular}{|l|}
\hline JUTE FIBRE \\
\hline BANANA FIBRE \\
\hline JUTE FIBRE \\
\hline BANANA FIBRE \\
\hline JUTE FIBRE \\
\hline BANANA FIBRE \\
JUTE FIBRE \\
\hline
\end{tabular}

Figure 6 Composition of Specimen A

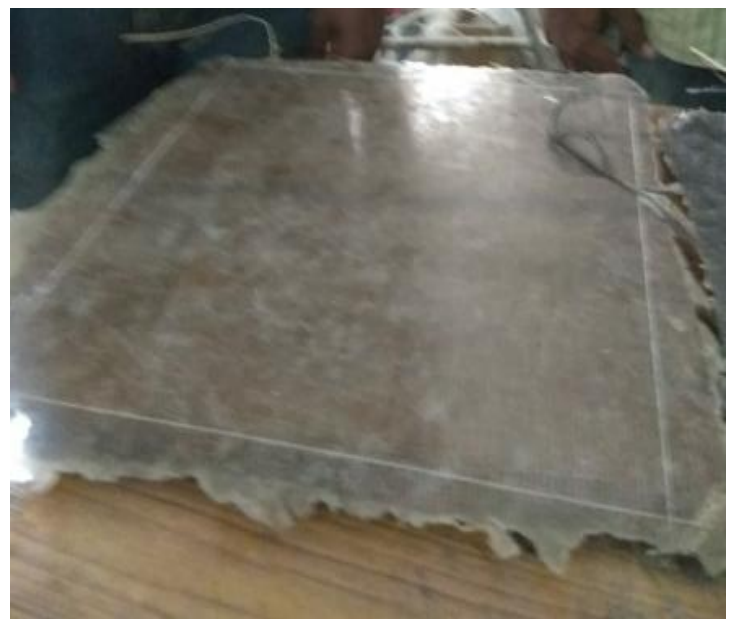

Figure 7 Prepared Specimen A

Specimen B consist only of natural fibres (banana and jute) and Carbon Fibre .The Composite is prepared by Hand lay-up method. Carbon Fibre is set as base material. Banana Fibre and Jute Fibre are kept over other sandwiched along with carbon fibre consisting of 7 layers. At the end of the process thickness is $6.5 \mathrm{~mm}$. The figure 8 represents the composition of the specimen B. The figure 9 depicts the prepared specimen B.

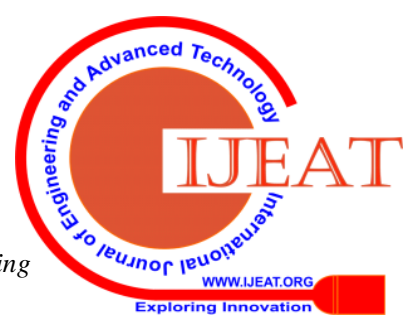




\begin{tabular}{|c|}
\hline CARBON FIBRE \\
\hline BANANA FIBRE \\
\hline JUTE FIBRE \\
\hline CARBON FIBRE \\
\hline BANANA FIBRE \\
\hline JUTE FIBRE \\
\hline CARBON FIBRE \\
\hline
\end{tabular}

Figure 8 Composition of Specimen B

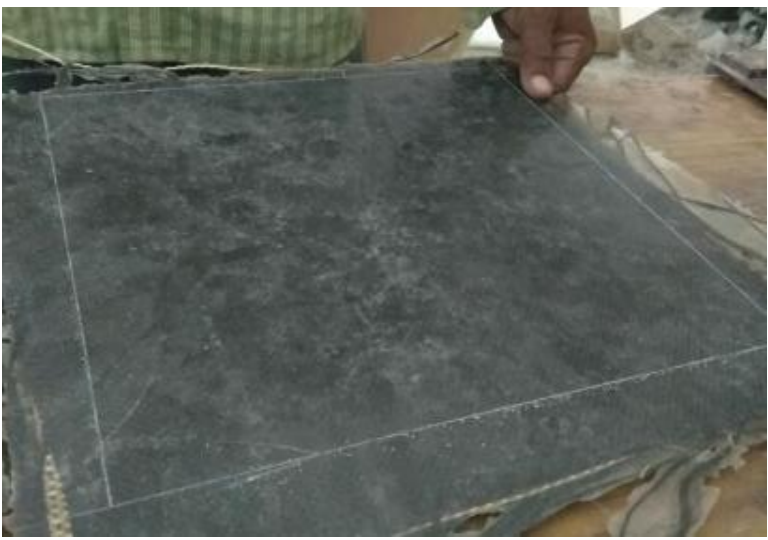

Figure 9 Prepared Specimen B

\section{MECHANICAL TESTING}

\section{Tensile Test}

Tensile test also known as universal engineering test is done to achieve material properties such as ultimate strength, yield strength and elongation. The applied load and extension are documented during the test for stress and strain calculation. The material specimen is prepared as per the ASTM D638 Standard. Two samples are taken for testing. $400 \mathrm{kN}$ capacity UTM is used for testing. A stress vs strain graph is bred. The table 3 represents the dimensions of prepared specimen A. The figure 10 and 11 indicates the tensile specimen A before and after testing in the UTM. The figures 12 and 13 represents the stress vs strain graph of the samples $\mathrm{A} 1$ and $\mathrm{A} 2$ respectively.

Table 3 Dimensions of tensile samples of specimen $A$

\begin{tabular}{|c|c|c|}
\hline Dimension & Sample A1 & Sample A2 \\
\hline Gauge Length & $1 \mathrm{~mm}$ & $1 \mathrm{~mm}$ \\
\hline Width & $13.25 \mathrm{~mm}$ & $13.2 \mathrm{~mm}$ \\
\hline Thickness & $6.88 \mathrm{~mm}$ & $6.87 \mathrm{~mm}$ \\
\hline
\end{tabular}

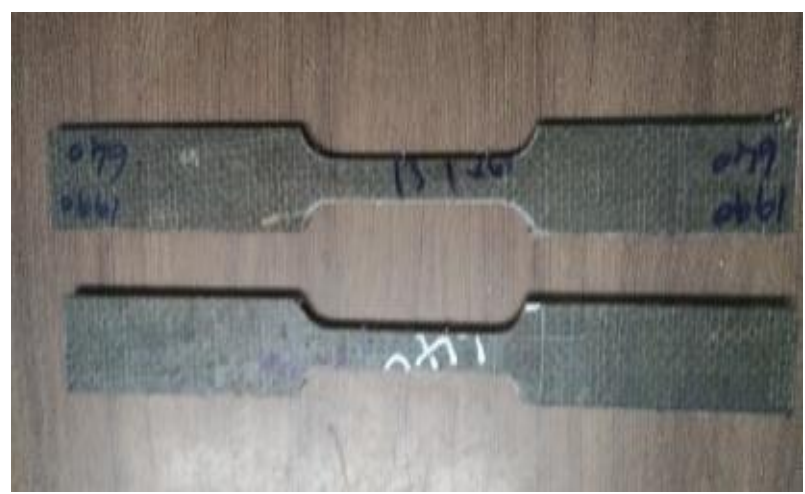

Figure 10 Tensile Samples of Specimen A before testing

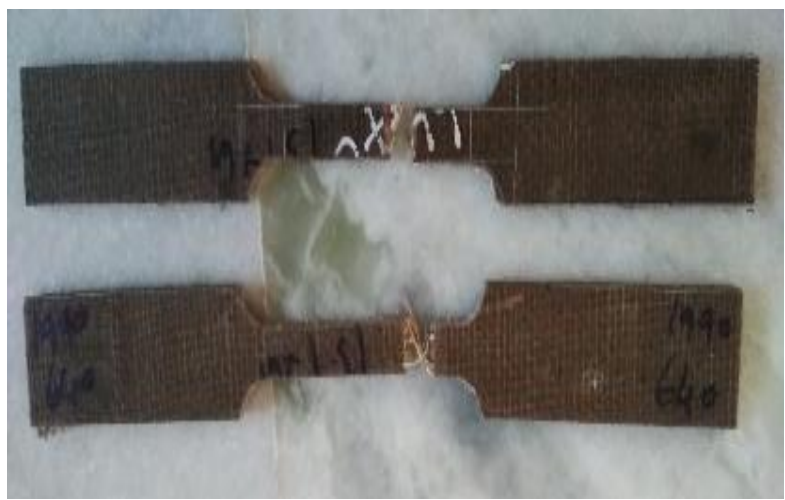

Figure 11 Tensile Samples of Specimen A after testing

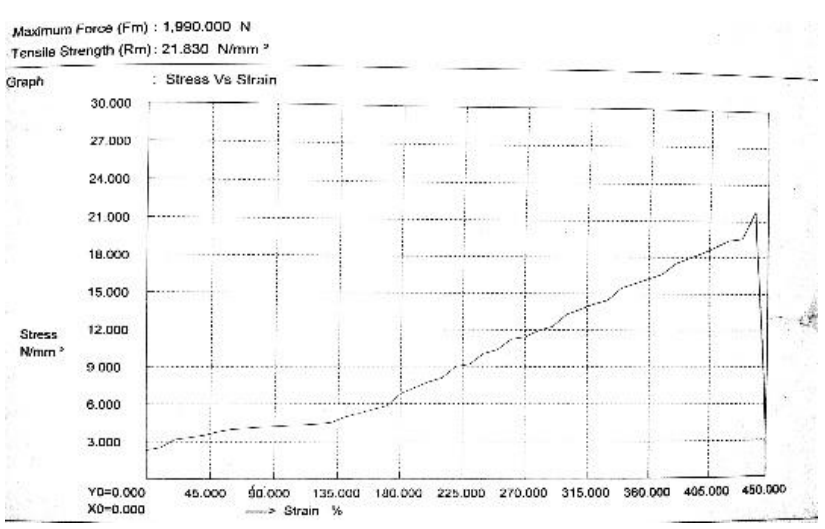

Figure 12 Stress vs strain graph for tensile sample A1

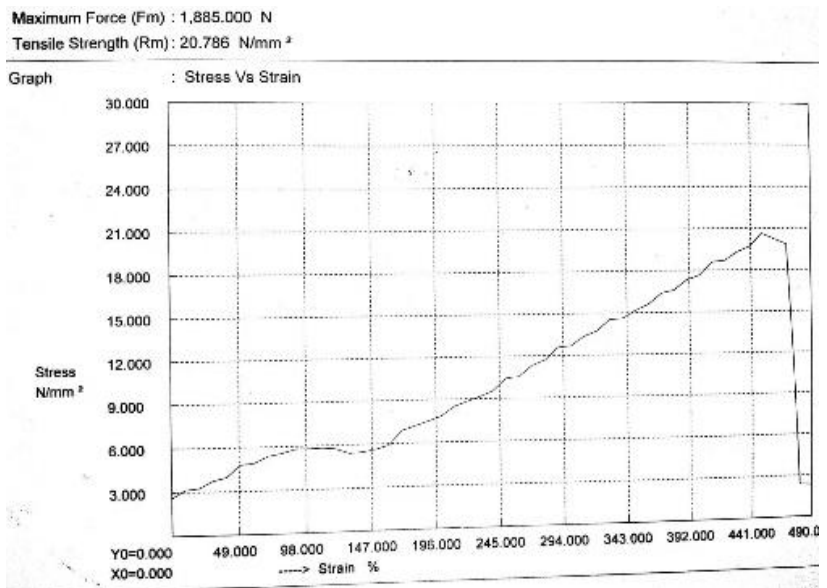

Figure 13 Stress vs strain graph for tensile sample A2 
The Results obtained from the above experiment are given in the below table 4 .

Table 4 Tensile test result of specimen $A$

\begin{tabular}{|c|c|c|c|}
\hline Tensile Test & $\begin{array}{c}\text { Sample } \\
\text { A1 }\end{array}$ & $\begin{array}{c}\text { Sample } \\
\text { A2 }\end{array}$ & $\begin{array}{c}\text { Average } \\
\text { Tensile } \\
\text { Strength }\end{array}$ \\
\hline $\begin{array}{c}\text { Maximum } \\
\text { Force (Fm) }\end{array}$ & $1990 \mathrm{~N}$ & $1885 \mathrm{~N}$ & \\
\hline $\begin{array}{c}\text { Tensile } \\
\text { Strength }(\mathrm{Rm})\end{array}$ & $\begin{array}{c}21.830 \\
\mathrm{MPa}\end{array}$ & $\begin{array}{c}20.786 \\
\mathrm{MPa}\end{array}$ & $\begin{array}{c}21.308 \\
\mathrm{MPa}\end{array}$ \\
\hline
\end{tabular}

The table 5 represents the dimensions of prepared specimen B. The figure 14 and 15 indicates the tensile specimen B before and after testing in the UTM. The figures 16 and 17 represents the stress vs strain graph of the samples $\mathrm{B} 1$ and $\mathrm{B} 2$ respectively.

Table 5 Dimensions of tensile samples of specimen $B$

\begin{tabular}{|c|c|c|}
\hline Dimension & Sample B1 & Sample B2 \\
\hline Gauge Length & $1 \mathrm{~mm}$ & $1 \mathrm{~mm}$ \\
\hline Width & $12.39 \mathrm{~mm}$ & $12.39 \mathrm{~mm}$ \\
\hline Thickness & $7.03 \mathrm{~mm}$ & $7.03 \mathrm{~mm}$ \\
\hline
\end{tabular}

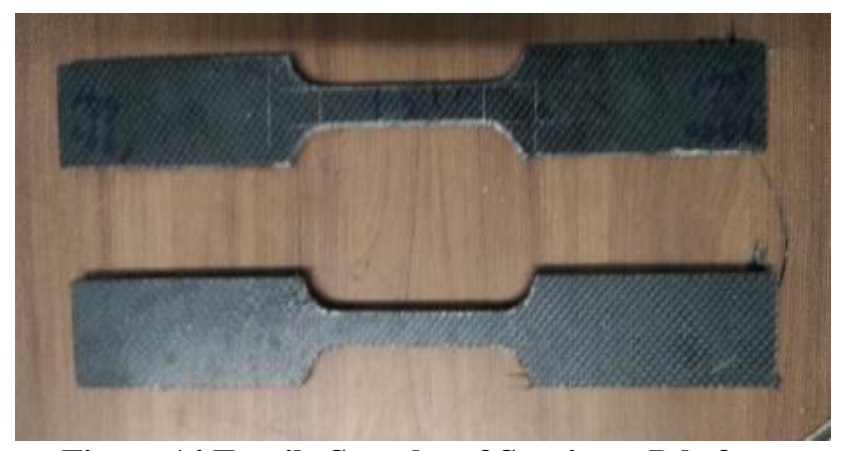

Figure 14 Tensile Samples of Specimen B before testing

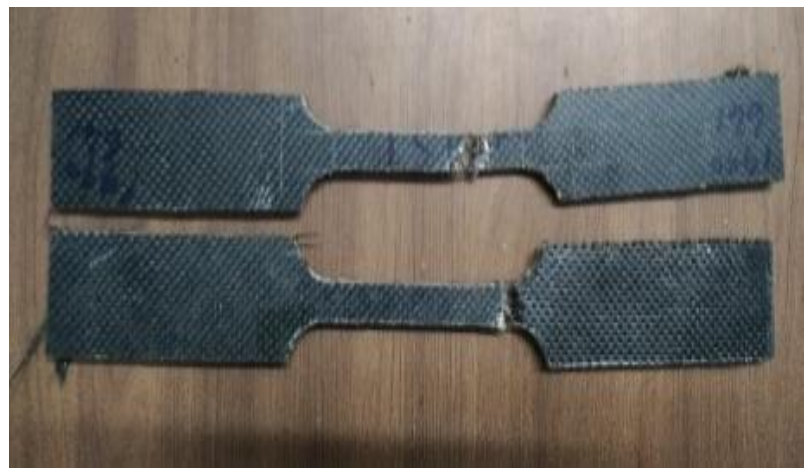

Figure 15 Tensile Samples of Specimen B after testing

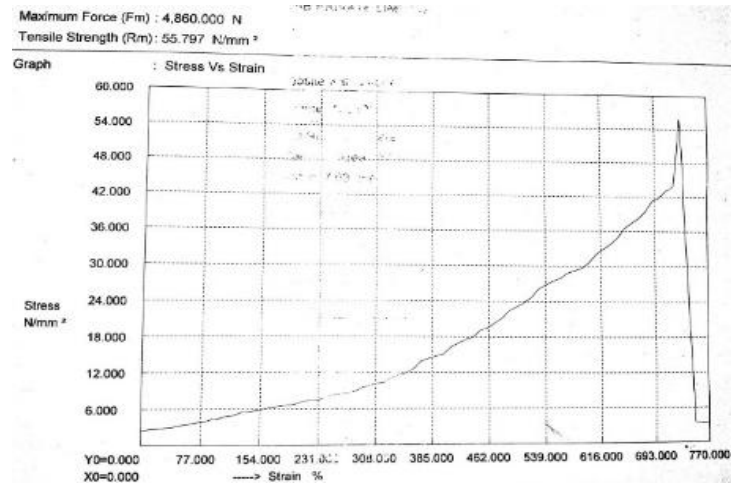

Figure 16 Stress vs strain graph for tensile sample B1

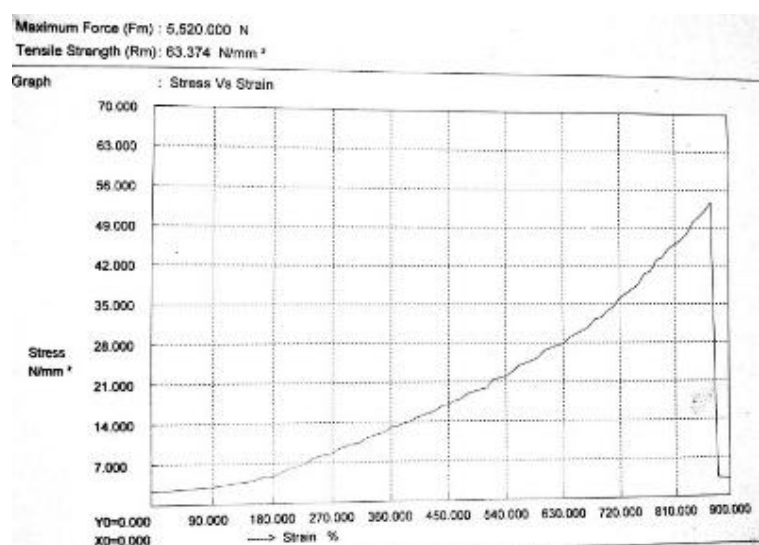

Figure 17 Stress vs strain graph for tensile sample B2

The Results obtained from the experiment are given in the below table 6 .

Table 6 Tensile test result of specimen $B$

\begin{tabular}{|c|c|c|c|}
\hline Tensile Test & $\begin{array}{c}\text { Sample } \\
\text { B1 }\end{array}$ & $\begin{array}{c}\text { Sample } \\
\text { B2 }\end{array}$ & $\begin{array}{c}\text { Average } \\
\text { Tensile } \\
\text { Strength }\end{array}$ \\
\hline $\begin{array}{c}\text { Maximum } \\
\text { Force (Fm) }\end{array}$ & $4860 \mathrm{~N}$ & $5520 \mathrm{~N}$ & \\
\hline $\begin{array}{c}\text { Tensile } \\
\text { Strength (Rm) }\end{array}$ & $\begin{array}{c}55.797 \\
\mathrm{MPa}\end{array}$ & $\begin{array}{c}63.374 \\
\mathrm{MPa}\end{array}$ & $\begin{array}{c}59.586 \\
\mathrm{MPa}\end{array}$ \\
\hline
\end{tabular}

\section{FLEXURAL LOAD TEST\& RESULTS}

Under three point loading conditions, the flexural test measures the required force to bend a beam. In this experiment, the material specimens are prepared as per the ASTM D790 Standard. For ASTM D790, the test is stopped when the specimen touches $5 \%$ deflection or when the specimen failures before $5 \%$. The figure 18 shows the test set up used for flexural test. The figure 19 shows the specimen prepared for the test. The figure 20 represents the flexural test specimen of Banana-Jute Composite (Specimen A). The figure 21 shows the flexural test specimen of Carbon Banana-Jute composite (Specimen B). The figure 22 represents the flexural test specimen of Banana-Jute composite after testing. The figure 23 shows the flexural test specimen of Carbon Banana-Jute composite after testing.

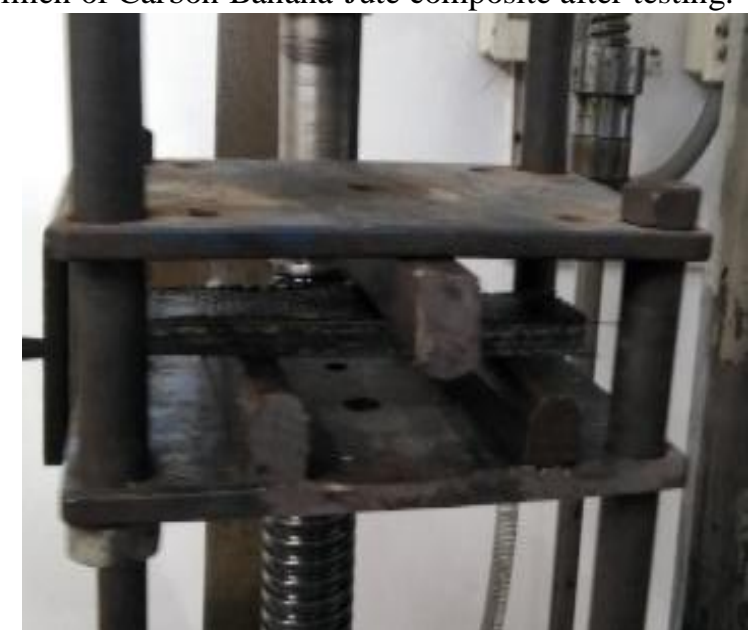

Figure 18 Flexural Test set up

Published By:

Blue Eyes Intelligence Engineering

\& Sciences Publication

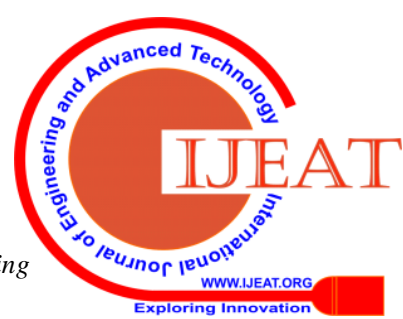




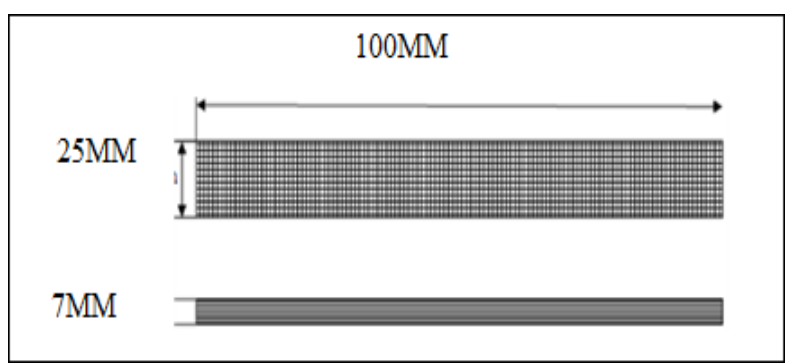

Figure 19 Flexural test specimen

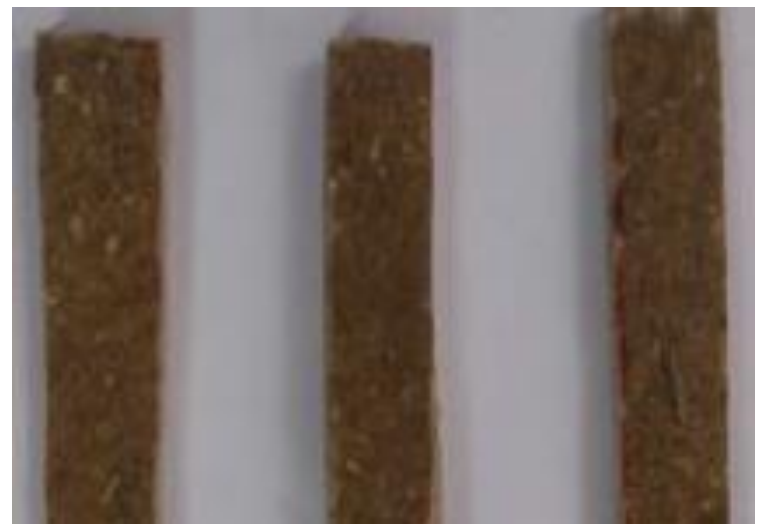

Figure 20 Flexural test Specimen of Banana-Jute Composite (Specimen A)

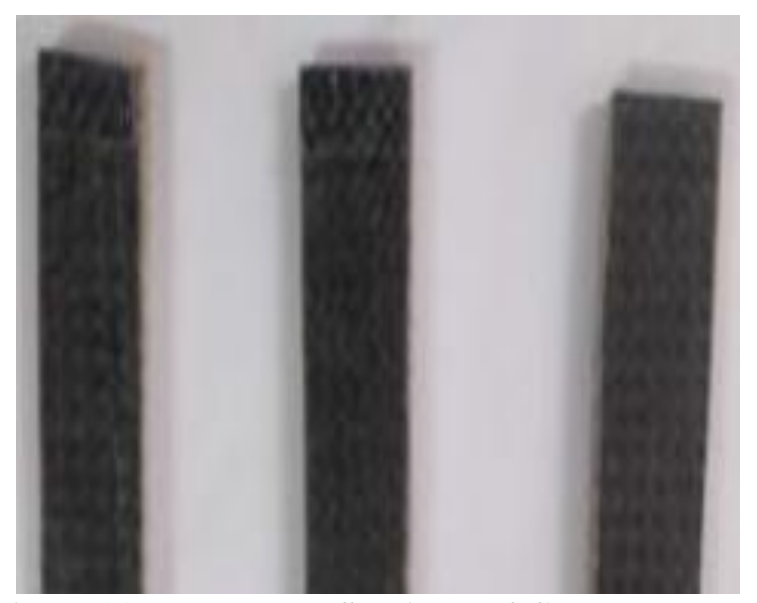

Figure 21 Flexural test Specimen of Carbon BananaJute composite (Specimen B)

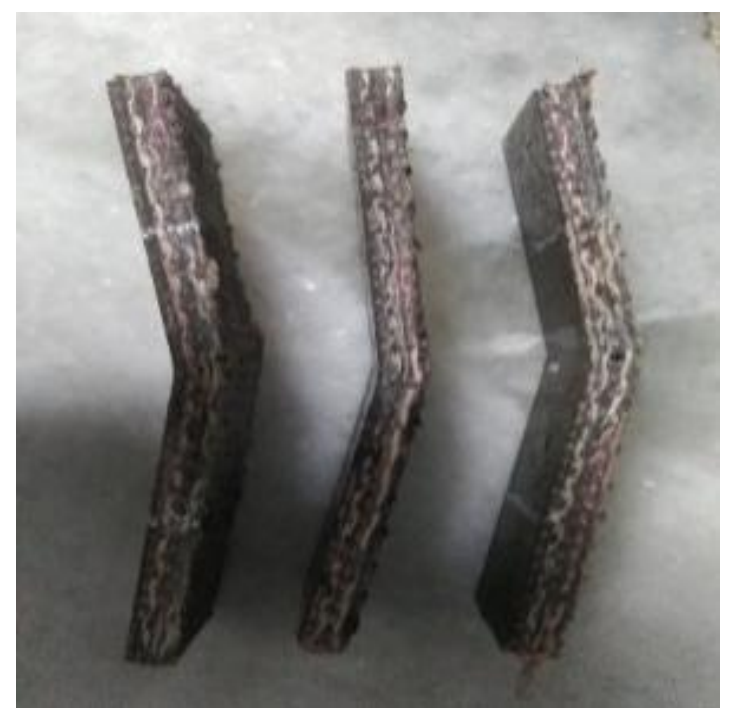

Figure 22 Flexural test Specimen of Banana-Jute composite after testing

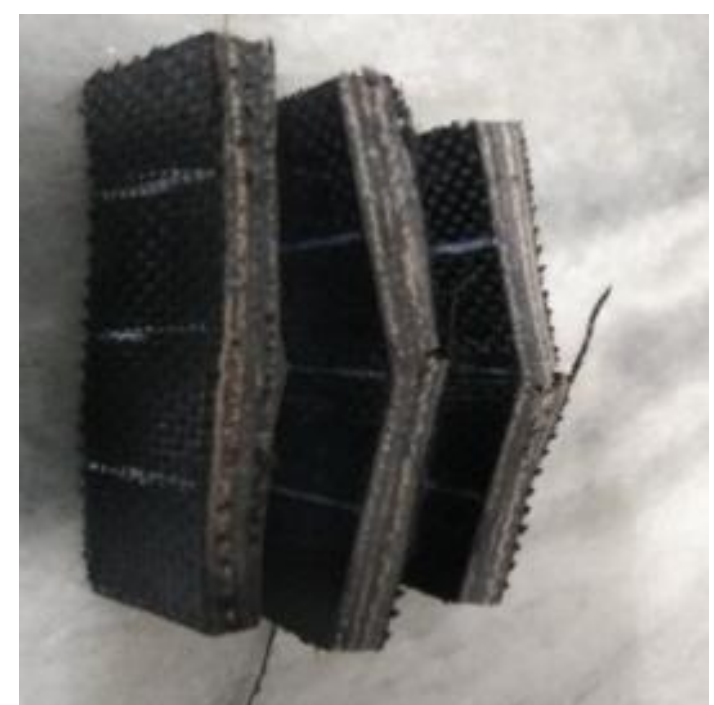

Figure 23 Flexural test Specimen of Carbon BananaJute composite after testing

The table 7 represents the flexural result obtained from the experiments conducted in the three point bending tests

Table 7 Flexural test result

\begin{tabular}{|c|c|c|}
\hline \multirow{2}{*}{ S.No } & $\begin{array}{c}\text { Banana+Jute } \\
\text { (Specimen A) }\end{array}$ & $\begin{array}{c}\text { Carbon + Banana + } \\
\text { Jute(Specimen B) }\end{array}$ \\
\cline { 2 - 3 } & $\begin{array}{c}\text { Flexural strength } \\
(\mathrm{MPa})\end{array}$ & $\begin{array}{c}\text { Flexural strength } \\
(\mathrm{MPa})\end{array}$ \\
\hline $1^{\text {st }}$ Specimen & 44.30 & 84.27 \\
\hline $2^{\text {nd }}$ Specimen & 78.18 & 88.99 \\
\hline $3^{\text {rd }}$ Specimen & 73.57 & 88.25 \\
\hline Average & 65.35 & 87.17 \\
\hline
\end{tabular}

\section{CONCLUSION}

The current research work depicts the potentiality of jute $\&$ banana fibre composites along with the carbon fibre, emphasizing both physical and mechanical properties.

The ultimate tensile strength of Banana-Jute composite is 21.308 MPa\& flexural strength is $65.35 \mathrm{MPa}$.

The ultimate tensile strength of Carbon Banana Jute composite is $59.586 \mathrm{MPa} \&$ flexural strength is $87.17 \mathrm{MPa}$.

It also emphasis variation in mechanical properties of composites of natural fibre when non-natural fibre such as carbon fibre is added in equal ratio.

The test shows the hybrid composites are much superior in properties than the homogenous composite.

Using this kind of composites in various applications are possible by these kinds of research findings.

\section{REFERENCES}

1. Silva RV, Spinelli D, Bose Filho WW, Claro Neto S, Chierice GO, Tarpani JR. Fracture toughness of natural fibers/castor oil polyurethane composites. Compos Sci Technol 2006;66:1328-35.

2. U Tamilarasan, L Karunamoorthy, K Palanikumar, "Tensile Property Evaluation of Carbon fiber Reinforced Aluminium Sandwich Composites", Advanced Materials Research, Vol 984. Pages 345-349.

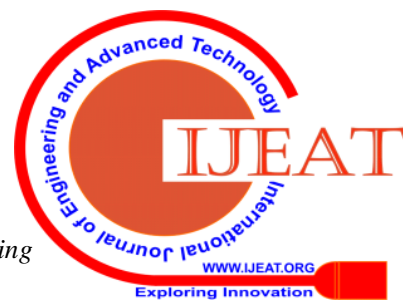


3. Tamilarasan U, L.Karanamoorthy, P.V. Inbanaathan, C.V. Jayakumar, Micro Structural Analysis of Cryogenically Treated Carbon fibre Reinforced Epoxy Laminates and Aluminium, special issue 01, Pages 559565.

4. Uthirapathy Tamilarasan, Loganathan Karunamoorthy, Kayaroganam Palanikumar, Mechanical properties evaluation of the carbon fibre reinforced aluminium sandwich composites, Materials Research, Vol 18, Issue 5, Pages 1029-1037.

5. MR Ashok, M Manojkumar, PV Inbanaathan, R Shanmuga Prakash, Flexural Behavior of Sandwich Structure with AA 8011 Honeycomb Core and Al 1100 Face Skins, International Journal of Vehicle Structures \& Systems, Vol 10, Issue 6, pages 404-406. 